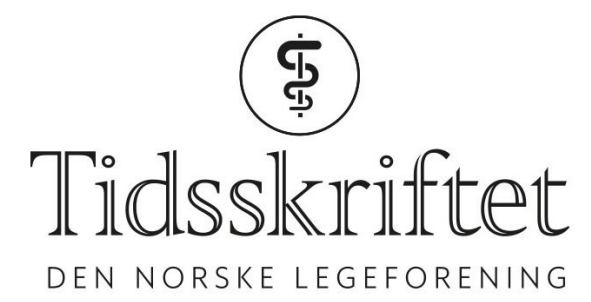

\title{
Styrk utdanningskapasiteten i Norge!
}

KOMMENTAR

MARIT HERMANSEN

E-post: marit.hermansen@legeforeningen.no

Marit Hermansen er president i Den norske legeforening.

Forfatteren har ikke oppgitt noen interessekonflikter.

Medisinstudent ved Universitetet i Bergen Gard Aasmund Skulstad Johanson etterlyser i Tidsskriftet den 29. oktober at Legeforeningen kommer på banen når det gjelder plassering av Grimstadutvalgets forslag om 440 nye studieplasser (1). Selv vil Skulstad Johansen ha alle de nye studieplassene plassert i dagens fire medisinske fakulteter.

Legeforeningen er glad for å se engasjement fra dagens studenter i det viktige spørsmålet om fremtidig utdanningskapasitet i Norge.

Landsstyret i Legeforeningen vedtok i 2016 at Norge burde utdanne $85 \%$ av legebehovet ved utdanningsinstitusjoner her i landet (2). Dette er fortsatt et viktig mål for foreningen. Vi $\emptyset$ nsker samtidig at noen leger utdanner seg utenfor Norge. Det gir et positivt og internasjonalt tilfang til vår helsetjeneste.

Legeforeningen er glad for Grimstadsutvalgets anbefalinger om 8o \% dekning nasjonalt (3).

Grimstadutvalget foreslår at det etableres 440 nye studieplasser i Norge der 120 av studieplassene foreslås til Vestlandet. Legeforeningen støtter at hele landet benyttes. På landsstyremøtet i 2016 ble det også anbefalt at utdanningen av fremtidens leger må innebære en større satsning på primærhelsetjenesten (2). Dette er i tråd med offentlige styringsdokumenter vedrørende både behov og analyser for hvordan medisinutdanningen best kan innrettes de kommende år. Stortinget har bedt regjeringen sikre at medisinstudenter får mer praksis i kommunehelsetjenesten (4). Legeforeningen mener at en samarbeidsmodell mellom universitetsmiljøene, aktuelle læringsarenaer både i primærhelsetjenesten, og de største sykehusene, vil bidra til fremtidsrettet utdanning. Dette vil også legge grunnlaget for en bærekraftig helsetjeneste.

$\emptyset$ kningen i antall studieplasser i Norge, kan ikke realiseres uten at myndighetene samtidig tar et tydeligere ansvar for utdanning av sitt eget helsepersonell. Det betyr at det må til en klar $\varnothing$ kning i antall LIS 1 stillinger og en betydelig satsing på LIS2og 3 parallelt.

Helsedirektoratets forslag om 200 nye LIS1- stillinger er en god begynnelse (5). Denne foreslåtte økningen i LIS1 stillinger er i tråd med Legeforeningens anbefalinger, men vi mener økningen må skje umiddelbart. Legeforeningen mener antallet stillinger må være basert på tjenestenes faktiske behov. Vi er i dag avhengig av en altfor stor andel import av spesialister, fordi vi ikke utdanner dem selv. Norge er helt i toppen i det vi importerer $43 \%$ av våre legespesialister fra utlandet (6).

I disse dager har Legeforeningen fått Grimstadutvalgets høring på bordet. Vi vil engasjere 
oss der, og videre i spørsmålet om hvordan vi best utdanner 440 nye leger i Norge og raskest få på plass 200 nye LIS1-stillinger i helsetjenesten i Norge.

\section{LITTERATUR:}

1. Johanson GAS. De medisinske fakultetene må øke utdanningskapasiteten. Tidsskr Nor Legeforen 2019; 139. doi: 10.4045/tidsskr.19.0627. [PubMed][CrossRef]

2. Grunnutdanning for leger - utvikling og harmonisering. Den norske legeforening, september 2016. https://beta.legeforeningen.no/contentassets/6e77afe794314c389bab4e777536fieb/grunnutdanningsra pport.pdf Lest 10.1.2020.

3. Studieplasser i medisin i Norge. Behov, modeller og muligheter. Utredning fra Grimstadutvalget. Oslo: Kunnskapsdepartementet, 2019.

https://www.regjeringen.no/contentassets/9b5b81d102384507b8515of2eofibo89/117459oo_rapport_utr edning_fra_grimstadutvalget.pdf. Lest 1.10.2019.

4. Innstilling fra helse- og omsorgskomiteen om Representantforslag fra stortingsrepresentantene Kjersti Toppe, Per Olaf Lundteigen, Willfred Nordlund og Iver Odnes om tiltak for å styrke rekruttering til og finansiering av fastlegeordningen, i tråd med intensjonene i samhandlingsreformen.

https://www.stortinget.no/no/Saker-og-publikasjoner/Publikasjoner/Innstillinger/Stortinget/2017-2018 |inns-201718-109s/?alltrue Lest 10.1.2020.

5. Helsedirektoratet. Foreslår opprettelse av 200 nye LIS1-stillinger.

https://www.helsedirektoratet.no/nyheter/foreslar-opprettelse-av-2oo-nye-lis1-stillinger Lest 10.1.2020.

6. Den norske legeforeningen. Legestatistikk. https://beta.legeforeningen.no/om-oss/legestatistikk/ Lest 10.1.2020.

Publisert: 3. februar 2020. Tidsskr Nor Legeforen. DOI: 10.4045/tidsskr.20.0029

(C) Tidsskrift for Den norske legeforening 2020. Lastet ned fra tidsskriftet.no 